\title{
UPAYA PENINGKATKAN PEMAHAMAN RUMUS PADA LUAS PERMUKAAN BANGUN RUANG SISI DATAR DENGAN METODE PENGAJARAN INQUIRY DISCOVERY LEARNING DAN PEMANFAATAN MEDIA TIGA DIMENSI DI SMP NEGERI 4 SIBABANGUN
}

\author{
Samson Panggabean \\ Guru Mata Pelajaran Matematika SMP Negeri 4 Sibabangun \\ samsonpanggabean7@gmail.com
}

\begin{abstract}
See the low understanding of student learning outcomes and on subjects of mathematics focused on, whether the application of the Learning Metode of inquiry - discovery learning with threedimensional media graphics can enhance the understanding of the students against the formula on the widespread the surface of the flat-sided room wake up on subjects of mathematics grade VIII SMP Negeri 4 even semester Sibabangun. The purpose of this class action research is to find out whether there is an increased understanding of the students against the surface area formula woke up flat-side space in the subject of mathematics the lesson using the learning metode of inquiry-discovery learning media with three-dimensional graphics. This research procedure includes twocycles where each cycle comprising planning, implementation, observation, and reflection. Class action research was conducted in the State JUNIOR 4 Sibabangun, with the object of research grade VIII totaling 42 students, consisting of 17 female students and 25 male students. The results showed that Math learning by using learning metode of inquiry-discovery learning can improve the understanding of the students against the formation of extensive formula is found waking up flat-side room with the results of the cycle I $59.04 \%$ and the cycle II $70.02 \%$, and (2) an increase in the diprosentasekan cycle 1 to cycle $2=$ $10.98 \%$.
\end{abstract}

Keywords: improve understanding of learning Media, three-dimensional graphics, metodes of inquiry-discovery learning.

\begin{abstract}
Abstrak
Melihat rendahnya pemahaman dan penilaian pengajaran siswa pada mata pelajaran Matematika difokuskan pada, apakah penerapan Metode pengajaran inquiry-discovery learning melalui media grafis tiga dimensi mampu peningkatan pemahaman siswa terhadap rumus pada luas permukaan bangun ruang sisi datar pada mata pelajaran matematika siswa kelas VIII semester genap SMP Negeri 4 Sibabangun. Tujuan penelitian tindakan kelas ini adalah untuk melihat adanya peningkatan pemahaman siswa terhadap rumus luas permukaan bangun ruang sisi datar pada pelajaran matematika yang pengajarannya menggunakan metode pengajaran inquirydiscovery learning dengan media grafis tiga dimensi. Prosedur penelitian ini mencakup 2 siklus dimana setiap siklus terdiri atas perencanaan, pelaksanaan, pengamatan, dan refleksi. Penelitian tindakan kelas ini dilaksanakan di SMP Negeri 4 Sibabangun, dengan objek penelitian siswa kelas VIII yang berjumlah 42 orang siswa yang terdiri atas 17 siswa perempuan dan 25 siswa laki-laki. Hasil penelitian menunjukkan bahwa pengajaran Matematika dengan menggunakan pengajaran metode inquiry-discovery learning memperoleh peningkatkan pemahaman siswa terkait mendapatkan pembentukan rumus luas bangun ruang sisi datar dengan hasil siklus I sebesar 59,04 \% dan siklus II sebesar 70,02 \%, dan (2) Peningkatan tersebut dapat diporsentasekan adalah siklus 1 ke siklus 2 sekitar 10,98\%.
\end{abstract}

Kata kunci: Pemahaman Belajar, Media Grafis Tiga Dimensi, inquiry-discovery learning.

115 | PeTeKa (Jurnal Penelitian Tindakan Kelas dan Pengembangan Pembelajaran) 


\section{PENDAHULUAN}

Setiap proses pengajaran terkadang tidak relevan dengan rencana, terkait pada komponen penilaian yang telah ditetapkan nilai kriteria ketuntasan belajar minimalnya (KKM). Ketidaksesuaian ini disebabkan oleh bermacam faktor yang mempengaruhinya, antara lain faktor internal dan faktor eksternal. Faktor internal adalah faktor yang terdapat dalam diri siswa, rendahnya minat, malas, dan sebagainya. Sedangkan faktor eksternal adalah faktor yang berada di luar diri siswa, faktor penampilan guru, metode yang diterapkan, media, lingkungan belajar, dan sebagainya.

Pada mata pelajaran matematika, evaluasi nilai selalu menjadi persoalan dan jauh dari harapan seperti yang telah ditetapkan secara nasional. Lebih rinci lagi, perolehan nilai ulangan harian selalu mendapat hasil yang tidak sesuai terutama pada materi bangun ruang sisi datar.

Tidak tercapainya perolehan nilai pada pokok bahasan bangun ruang sisi datar disebabkan oleh banyaknya rumus yang harus dikuasai oleh siswa. Kebanyakan guru beranggapan bahwa bila menghapal rumus maka siswa pasti mampu menyelesaikan soal. Bila beranggapan seperti itu metode yang digunakan hanya menghafal dan memberikan tugas. Pengajaran seperti ini tidak tertuju pada permasalahan yang ditemukan siswa, sehingga pengajaran tidak bernilai. Siswa tidak paham bagaimana rumus itu ditemukan, dan bagaimana cara menggunakannya.

Kata Media berasal dari bahasa latin medius yang secara harfiah berarti tengah, perantara, atau pengantar. Tetapi secara lebih khusus, pengertian media dalam proses pengajaran cenderung diartikan sebagai alat atau grafis, fotografis, atau elektroniks untuk menangkap, memproses, atau menyusun kembali informasi visual atau verbal (Angkowo dan Kosasih : 2007). Sedangkan Djamarah (2006) menyatakan bahwa media dapat diartikan dengan manusia, benda, ataupun peristiwa yang memungkinkan anak didik memperoleh pengetahuan dan keterampilan.

Seterusnya Angkowo dan Kosasih (2007) Ciri-ciri khusus media pengajaran berbeda menurut tujuan dan pengelompokkannya. Ciri-ciri media dapat dilihat menurut kemampuannya membangkitkan rangsangan pada indera penglihatan, pendengaran, perabaan, penciuman, dan pengecapan. Media pengajaran sebagai salah satu sumber belajar ikut membantu guru memperluas wawasan siswa. Bermacam media yang dijadikan sebagai sumber belajar menjadi pengalaman dan pengetahuan yang baik bagi siswa.

Inquiry-discovery learning adalah belajar mencari dan menemukan sendiri (Djamarah, \& Zain, 2006). Dalam sistem belajar-mengajar ini ini guru menyajikan bahan pengajaran tidak sampai pada bentuk final, tetapi siswa diberi peluang untuk mencari dan menemukan sendiri. Siswa belajar terlibat aktif dengan konsep dan prinsip, dan guru hanya sebagai motivator siswa untuk melakukan percobaan.

Metode pengajaran Inquirydiscovery pada pelajaran eksakta membantu siswa memahami konsep yang sulit dengan menggunakan demonstrasi dan gambar atau media tiga dimensi, sehingga belajar dapat fleksibel dan eksploratif (Mustaji, 2005). Pada pengajaran ini ada bermacam tujuan yang dapat diraih, tujuan dapat diraih tersebut antara lain; kesatu, pemenuhan informasi yang tidak asing bisa memperkuat struktur 
Samson Panggabean. Upaya Meningkatkan Pemahaman Rumus Pada Luas...

pengetahuan siswa. Kedua, kembali ke konsep sulit, dan mengajak siswa berdiskusi secara mendetail. Ketiga, mengkaji ulang persoalan yang rumit, siswa biasa melihat solusi yang tampak sebelumnya. Keempat, menunjukkan materi dari banyak anggapan dan mengerjakan masalah yang tidak terpecahkan bisa membantu siswa meningkatkan kemampuan pengetahuannya.

\section{METODE}

Bentuk penelitian ini merupakan penelitian tindakan kelas (Classroom Action Research) sedangkan strategi yang dilakukan adalah melalui pendekatan kontekstual dengan memanfaatkan lingkungan sekitar untuk meningkatkan kreatifitas dan kompetensi belajar siswa pada pelajaran matematika. Penelitian tindakan kelas ini adalah PTK metode Kurt Lewin yang terdiri dari empat komponen yaitu perencanaan (Planning), tindakan (acting), pengamatan (Observating), dan refleksi (reflecting). Keterkaitan keempat komponen itu dipandang sebagai 1 siklus. Penelitian ini dilaksanakan melalui 2 siklus (Arikunto, 2007).

\section{Perencanaan Tindakan}

Melalui tindakan ini penulis melakukan action research tentang rencana tindakan yang dilakukan. Adapun tindakan yang dilaksanakan penulis pada kegiatan ini sebagai berikut:

1. Membuat lembar pengamatan (observasi), monitoring dan lembar kerja siswa (LKS) sebagai alat-alat penelitian.

2. Mengajak siswa untuk belajar materi bangun ruang sisi datar yang berbentuk kubus, balok, limas dan prisma yang telah disajikan dalam bentuk gambar dan alat peraga.

3. Membuat siswa menjadi 7 kelompok, masing-masing kelompok terdiri dari 6 orang.

4. Menyiapkan alat peraga bangun ruang.

5. Membagikan lembar kerja siswa (LKS) pada tiap kelompok.

6. Melaksanakan pengamatan, dan memberikan soal-soal.

7. Menyusun rencana pengajaran dengan langkah - langkah :

Tabel 1: Langkah Persiapan Tindakan

\begin{tabular}{|c|c|c|c|c|c|}
\hline $\begin{array}{l}\text { No.sk / } \\
\text { kd }\end{array}$ & $\begin{array}{l}\text { Standar Kompetensi / } \\
\text { Kompetensi Dasar }\end{array}$ & $\begin{array}{l}\text { Alo } \\
\text { kasi }\end{array}$ & Metode & $\begin{array}{l}\text { Rencana } \\
\text { Pengajaran }\end{array}$ & $\begin{array}{l}\text { Hasil } \\
\text { Tindakan }\end{array}$ \\
\hline 2.1 & Materi Kubus dan balok & & & & \\
\hline 2.1 .1 & $\begin{array}{l}\text { Bagian - bagian kubus } \\
\text { dan balok }\end{array}$ & 2 & $\begin{array}{l}\text { Kubus, } \\
\text { balok }\end{array}$ & I & $\begin{array}{l}\text { Peningkatan } \\
\text { pemberian } \\
\text { motivasi }\end{array}$ \\
\hline 2.1 .2 & $\begin{array}{l}\text { Menentukan jaring- } \\
\text { jaring kubus dan balok }\end{array}$ & 2 & $\begin{array}{l}\text { Inquiry- } \\
\text { discovery } \\
\text { learning }\end{array}$ & II & $\begin{array}{l}\text { Pemberdayaan } \\
\text { siswa }\end{array}$ \\
\hline 2.1 .3 & $\begin{array}{l}\text { Mencari rumus luas } \\
\text { permukaan kubus dan } \\
\text { balok. }\end{array}$ & 2 & $\begin{array}{l}\text { Inquiry- } \\
\text { discovery } \\
\text { learning }\end{array}$ & III & $\begin{array}{l}\text { Pemberdayaan } \\
\text { siswa }\end{array}$ \\
\hline
\end{tabular}


Tabel 2: Tahap Penerapan Pelaksanaan

\begin{tabular}{|c|c|c|c|}
\hline Siklus & Tahap I & Tahap II & Tahap III \\
\hline II & $\begin{array}{l}\text { 4 Januari } 2018 \\
\text { - PBM sub. 2.1.1 } \\
\text { - Apersepsi } \\
\text { - PBM ditetapkan } \\
\text { Pengenalan bagian - } \\
\text { bagian bangun ruang sisi } \\
\text { datar kubus dan balok } \\
\text { 14 Februari } 2018 \\
\text { - PBM refleksi Siklus I } \\
\text { Tahap I } \\
\text { - Penilaian kelompok } \\
\text { dengan metode enquiry- } \\
\text { discovery }\end{array}$ & $\begin{array}{l}4 \text { Maret } 2018 \\
\text { - } \quad \text { PBM refleksi Siklus I } \\
\text { Tahap I dan II } \\
\text { - Penilaian Kelompok } \\
\text { Dengan metode } \\
\text { Enquiry-discovery } \\
\text {-Pemaparan Kerja } \\
\text { Kelompok }\end{array}$ & $\begin{array}{l}\text { 7- } 8 \text { Februari } 2018 \\
\text { - PBM refleksi sub } 2.1 .2 \\
\text { •PBM sub 2.1.3 } \\
\text { - Penilaian kelompok } \\
\text { dengan metode } \\
\text { enquiry-discovery } \\
\text { Analisa Siklus I } \\
11 \text { - } 26 \text { Maret } 2018 \\
\text { - PBM gambaran Siklus } \\
\text { I } \\
\text { Tahap II dan III } \\
\text {-Penilaian Kelompok } \\
\text { Dengan metode } \\
\text { Enquiry- } \\
\text { discovery } \\
\text {-Pemaparan Kerja } \\
\text { Kelompok } \\
\text {-Penilaian Siklus II } \\
\text { •Penyusunan Laporan }\end{array}$ \\
\hline
\end{tabular}

\section{Pelaksanaan Tindakan}

Pada tahap ini adalah penerapan langkah pengajaran yang diterapkan.

Adapun langkah pengajaran yang ditentukan antara lain :

Tabel 3: Langkah Pengajaran Inquiry-Discovery

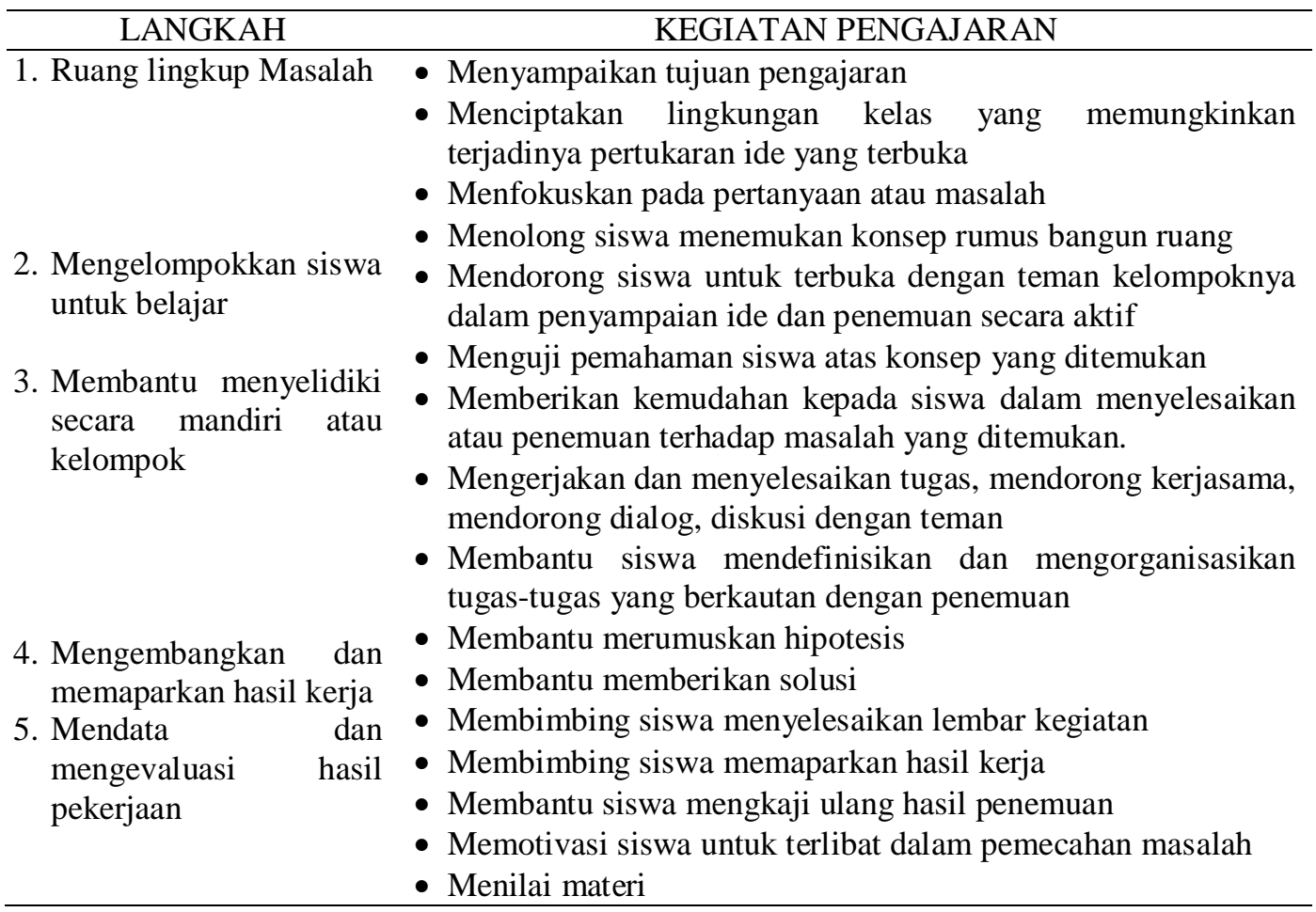


Samson Panggabean. Upaya Meningkatkan Pemahaman Rumus Pada Luas...

\section{Pengamatan atau Observasi}

Melalui tahap ini sebenarnya berlangsung bersamaan dengan rencana pengajaran. Penulis melakukan pengamatan terhadap kegiatan pengajaran yang sedang berlangsung. Pengamatan ini sebagai penilaian proses yang dinilai dalam lembar pengamatan .

\section{Refleksi}

Dalam tahap ini penulis membahas ulang secara menyeluruh terhadap tindakan penelitian yang dilaksanakan. Pada tahap selanjutnya dilakukan analisis, sintesis, dan penilaian terhadap hasil pemantauan atas kegiatan yang telah dilaksanakan.

\section{HASIL DAN PEMBAHASAN}

Pada penelitian ini menggunakan angket kuesioner sebagai alat utama yang diberikan pada 42 responden di kelas VIII semester genap SMP Negeri 4 Sibabangun. Pada bagian ini akan disajikan data hasil penelitian, secara berturut-turut diuraikan 2 hal antara lain : yaitu (1) Hasil penelitian, (2) Pembahasan hasil penelitian.

Penghitungan dan analisis data yang diterapkan adalah analisisis deskriptif, yaitu menggambarkan atau mendeskripsikan serta menetapkan kecenderungan data. Adapun langkahlangkah analisis sebagai berikut:

1. Data hasil penelitian dihitung secara nominal.
2. Data perhitungan data digambarkan dalam bentuk histogram.

3. Data histogram bentuk angka prosentase.

4. Angka prosentase digambarkan berdasarkan kecenderungan tindakan yang dilakukan guru dan reaksi siswa sebagai upaya peningkatan pemahaman rumus pada luas permukaan bangun ruang sisi datar dengan metode pengajaran inquirydiscover learning.

Ingin mengetahui adanya peningkatan atau tidak dalam mengikuti proses pengajaran menemukan rumus bangun ruang sisi datar dengan metode pengajaran inquiry-dicovery, maka akan dibandingkan tanggapan siswa berdasarkan selisih prosentase dengan diberi perlakuan tindakan.

\section{Hasil Observasi Proses Pengajaran}

Kesimpulan : Dari 42 responden terdapat peningkatan minat dalam mengikuti pengajaran menemukan pembentukan rumus luas bangun ruang sisi datar dengan metode pengajaran inquiry-discovery learning . Gambaran histogram hasil pengolahan data ratarata untuk observasi proses pengajaran dalam siklus 1 sebesar $60,47 \%$ dan Siklus 2 sebesar 71,55\%. Sehingga demikian minat siswa dalam pengajaran menjumpai proses pembentukan rumus luas bangun ruang sisi datar kubus dan balok mengalami peningkatan sebesar $11,08 \%$.

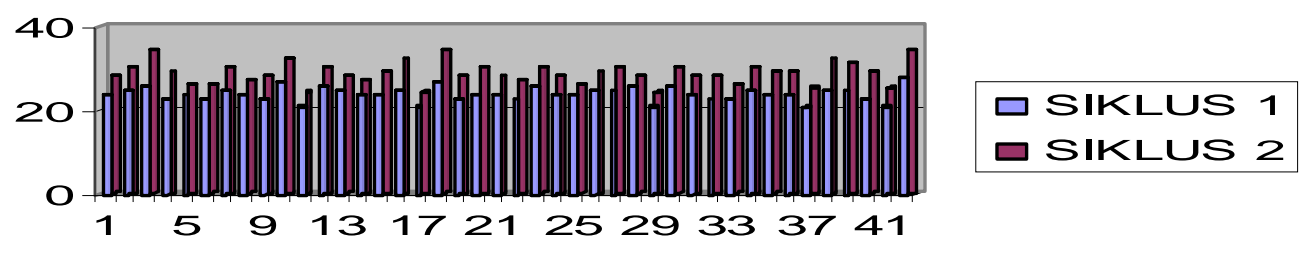

Gambar1: Grafik Hasil Pengamatan Proses Pengajaran pada per siklus 


\section{Hasil Angket Proses Pengajaran}

\section{Siswa}

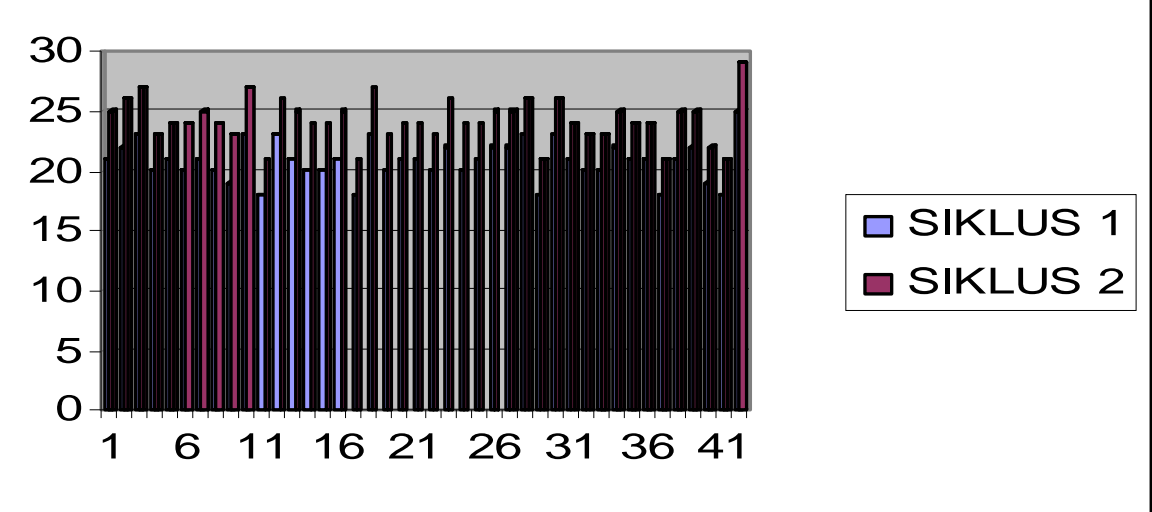

Gambar 2: Grafik Hasil Angket Proses Pengajaran siswa pada per siklus

Kesimpulan : Terlihat 42 responden ditemukan kenaikan kegiatan siswa ketika mengikuti pengajaran menemukan pembentukan rumus luas bangun ruang sisi datar kubus dan balok dengan metode pengajaran inquiry-discovery learning. Berdasarkan histogram hasil pengolahan data siswa rata-rata angket siswa dalam pengajaran pada siklus 1 sebesar 69,44\% dan Siklus 2 sebesar 80,79\%. Berdasarkan prosentase masing-masing siklus tersebut, terdapat peningkatan aktivitas pengajaran sebesar 11,35\%.

\section{Bagi guru}

Kesimpulan : Terkait histogram hasil pengolahan data angket guru dalam pengajaran menemukan pembentukan rumus luas bangun ruang sisi datar kubus dan balok dengan metode pengajaran inquiry-discoverylearning rata-rata hasil angket siklus 1 sebesar 70\%, dan siklus 2 sebesar $83 \%$. Melihat angket tersebut maka kegiatan guru dalam pengajaran menunjukkan peningkatan $13 \%$.

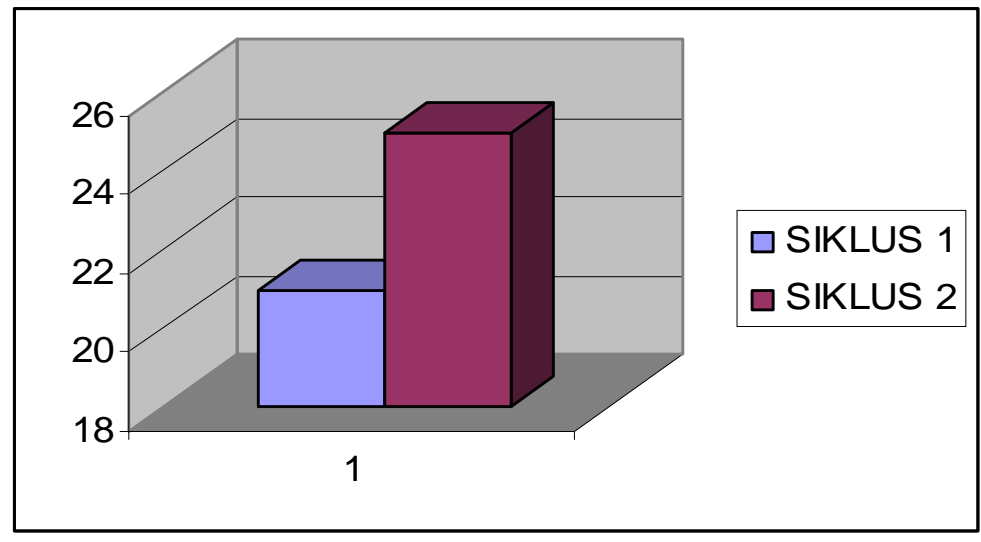

Gambar. 3: Histogram Aktivitas Guru pada per siklus 
Hasil Wawancara Proses Pengajaran Wawancara Siswa

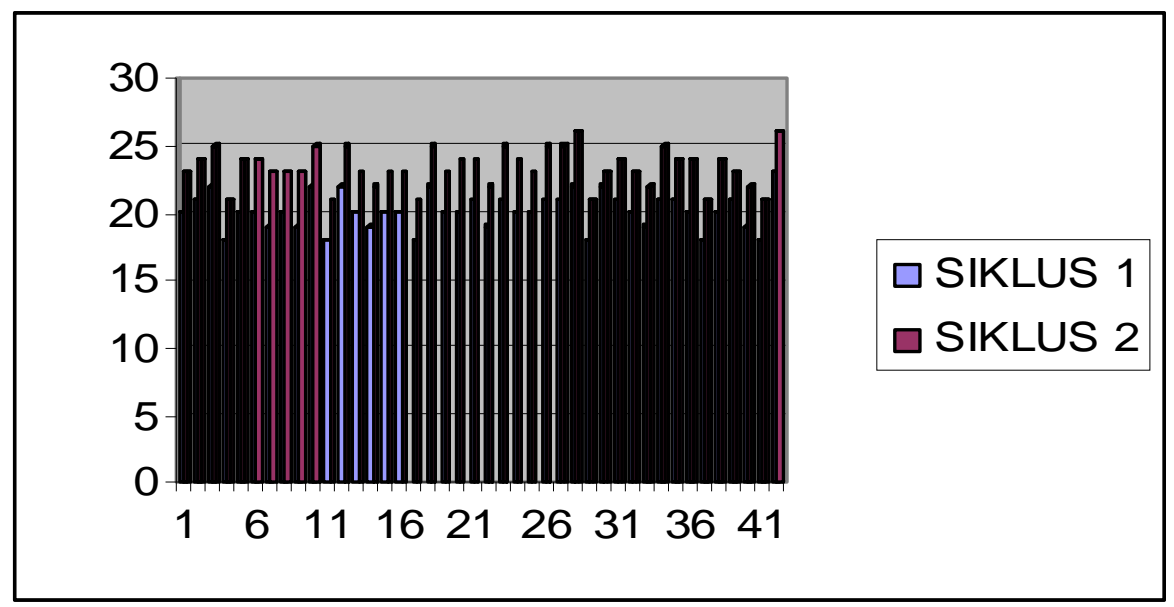

Gambar 4: Grafik Hasil Wawancara pada per siklus

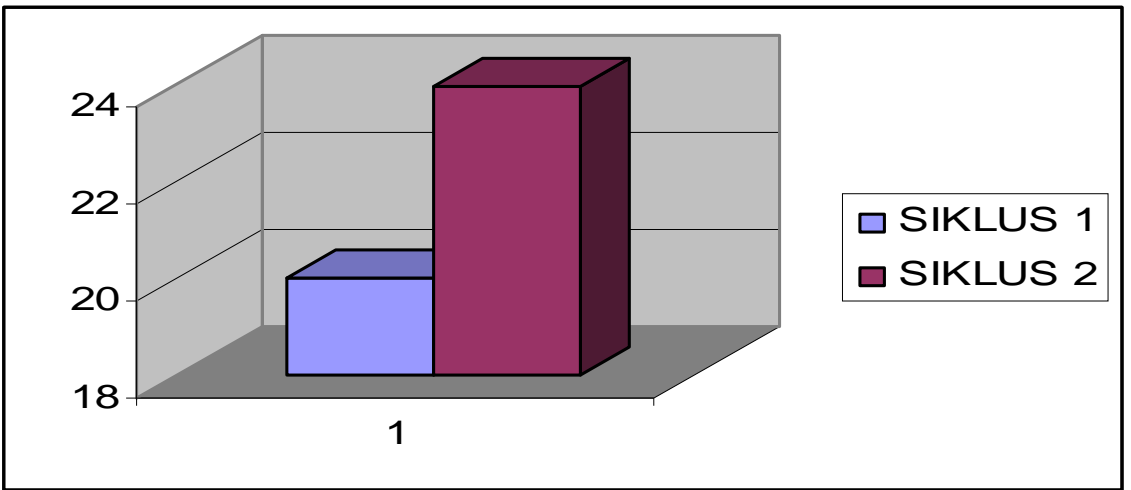

Gambar 5: Histogram Hasil Wawancara guru pada per siklus

Kesimpulan : Melihat gambar histogram hasil pengolahan data wawancara siswa dalam proses pengajaran menemukan pembentukan rumus luas bangun ruang sisi datar kubus dan balok dengan metode pengajaran inquiry-discoverylearning re-rata hasil wawancara pada siswa, siklus $1=66,14 \%$, dan siklus $2=$ 77,93\%. Melihat data itu terlihat respon terhadap pengajaran menunjukkan kenaikan sebesar $11,79 \%$.

\section{Wawancara Guru}

Kesimpulan : Dengan melihat histogram hasil pengolahan data wawancara guru dalam proses pengajaran mengalami kenaikan kegiatan. Siklus 1 sebesar 67\%, dan siklus 2 sebesar $\mathbf{8 0 \%}$.Sehingga wawancara dengan guru tersebut respon terhadap pengajaran dengan metode Inquiry-discovery learning mengalami kenaikan sebesar $\mathbf{1 3} \%$.

\section{Hasil Tes}

Dengan hasil tes diperoleh nilai re-rata pada siklus 1 sebesar 59,04, pada siklus2 sebesar 70,02. Dari uraian data tersebut terdapat peningkatan hasil belajar sebesar $10,98 \%$. 
Dengan demikian pengajaran menemukan pembentukan rumus luas bangun ruang sisi datar dengan metode pengajaran inquiry-discovery learning terjadi peningkatkan pemahaman siswa yang ditandai dengan meningkatnya nilai hasil belajar pada setiap siklus penelitian yang dilakukan. Peningkatan ini dapat di lihat dari re-rata nilai yang diperoleh pada siklus 2 dalam prosentase pencapaiannya.

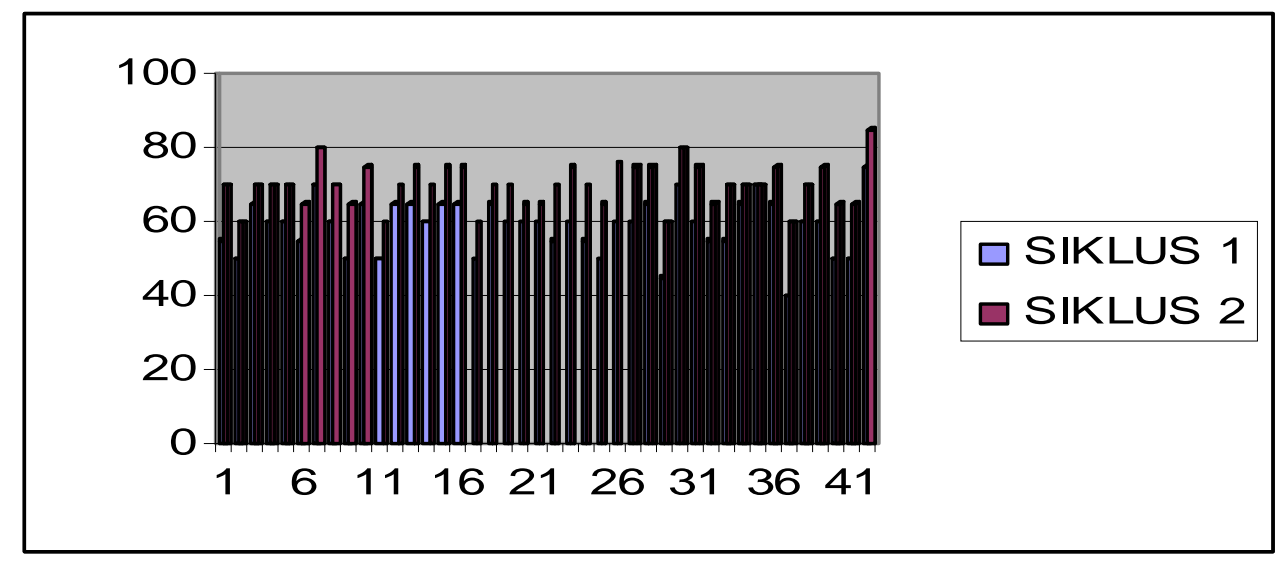

Gambar 6: Grafik Hasil Tes pada Per Siklus

\section{SIMPULAN}

Oleh sebab itu melalui data hasil penelitian, maka dapat disimpulkan bahwa pengajaran matematika pada pokok bahasan menemukan proses pembentukan rumus pada luas bangun ruang sisi datar dengan metode pengajaran inquiry-discovery learning memiliki dampak yang besar dalam peningkatkan hasil belajar siswa kelas VIII semester genap SMP Negeri 4 Sibabangun. Besarnya pengaruh tersebut. Metode pengajaran inquirydiscovery learning mampu meningkatkan pemahaman siswa terhadap menemukan pembentukan rumus luas bangun ruang sisi datar. Hasil ini dibuktikan berdasarkan siklus 1 memperoleh rata-rata nilai tes siklus 1 sebesar 59,04\% dan siklus 2 sebesar $70.02 \%$.

Kenaikan tersebut dapat diprosentasekan sebagai berikut; Siklus 1 ke siklus 2 sebesar $10,98 \%$ Oleh sebab itu terbukti bahwa pengajaran menemukan pembentukan rumus luas bangun ruang sisi datar dengan metode pengajaran inquiry-discovery learning, dapat meningkatkan hasil belajar.

DAFTAR PUSTAKA

Arikunto, Suharsimi. 2007. Penelitian Tindakan Kelas. Jakarta: Bumi Aksara.

Angkowo.R, dan A. Kosasih. 2007. Optimalisasi Media Pengajaran. Jakarta: PT Grasindo.

Djamarah, Syaiful. 2006. Guru dan Anak Didik dalam Interaksi Edukatif. Jakarta: Rineka Cipta.

Djamarah, S. Bahri. dan Zain A. 2006. Strategi Belajar Mengajar. Jakarta: Rineka Cipta.

Mustaji dan Sugiarso. 2005. Pengajaran Berbasis Konstruktivistik. Surabaya: UNESA University Press. 